\title{
Network Culture, Performance \& Corporate Responsibility
}

\author{
Silvio M. Brondoni ${ }^{*}$
}

\begin{abstract}
The growth and sustainability of free market economies highlights the need to define rules more suited to the current condition of market globalisation and also encourages firms to adopt more transparent and accountable corporate responsibility (and corporate social responsibility, namely the relationship between the company, environment and social setting).

From a managerial perspective, corporate responsibility is linked to ensure the lasting pursuit of the company mission, seeking increasing levels of quality and efficiency.

Corporate responsibility in global markets aims to pursue business results (local and corporate) that feature high levels of profitability and efficiency, but also a priority concern for sustainable development.

In global companies, corporate social responsibility is targeted at managing the stakeholder system (i.e. all those with an organizational, social or environmental interest).
\end{abstract}

Keywords: Corporate Responsibility; Corporate Social Responsibility; Global Markets; Sustainable Growth; Networking; Network Culture; Local \& Global Performance

\section{Corporate Responsibility, Global Markets and Sustainable Growth}

The debate over corporate conduct in a context of sustainable development has taken on new importance in recent times. It is an area that generates great interest among public opinion; a public increasingly well-informed and attentive to the ethical aspects of the company and prepared to recognise the lead played by those companies with responsible and socially oriented behaviour.

Indeed, the growth and sustainability of free market economies highlights the need to define rules more suited to the current condition of market globalisation and also encourages companies to adopt more transparent and accountable corporate responsibility behaviour, whilst developing at the same time more effective activities of prevention, monitoring and containment ${ }^{1}$. Corporate

\footnotetext{
*Full Professor of Management, University of Milan-Bicocca (silvio.brondoni@ unimib.it)
} 
responsibility (and more specifically, corporate social responsibility, namely the relationship between the firm, environment and social setting) has actually already been the subject of much debate in the past, whenever the economic systems have registered profound changes to production, distribution or consumption processes.

Thus, in the mid-'50s (when the tumultuous development of the so-called 'economy of scarcity' ended and the 'welfare state' cycle began ${ }^{2}$ ), when Ford production and the expansion of mass consumption was in full maturity, we should stress 'the importance of not only economic performance in corporate decisionmaking, but also of the related social effects', thereby stimulating a company's social responsibility and its 'duty to pursue those policies that are deemed desirable when placed alongside the objectives and values recognized by Society ${ }^{3}$.

As such, the 'welfare state' spread a new 'phase of both theoretical and politicaleconomic transformation, which developed between the two world wars and the society of the Keynesian New Deal period based on some basic tenets: a clear division of roles between the State and the market. the affirmation of renewed company governance, based on management's increasing role. and the approval of innovative legislation and organization of public control bodies with the capacity to safeguard the balanced functioning of the market and financial system ${ }^{4}$.

Therefore, in the 'welfare state', the firm becomes a component in social equilibrium, where the central role is played by a renewed State-market relationship that goes well beyond a company's extensive independence in the classic liberal economic order ${ }^{5}$. In this new context, corporate responsibility undergoes a profound transformation. A company and its activities are well and truly focused on the international aspect of markets and requires new management skills, which - on the whole - require that governance duties are separate from management functions (with company owners progressively assisted by professional managers). Markets and businesses, therefore, become increasingly international and extensive, although the headquarters actually remain located in the countries of origin (thus, in practice, they limit themselves merely to competing hard in the export of goods). Consequently, a new concept of corporate social responsibility develops, with a strong national identity in terms of legislation, principles of public government and consolidated social values, but one that balances business performance against certain social values of corporate interest, such as the development of the rights and satisfaction of consumer expectations or even greater attention to worker protection. In brief, a firm no longer detached from the social system but at the centre of a social system with a predominance of wide-ranging national rules.

$\square$ The huge Ford-style factory of the 50s and 60s pursued the objective of guaranteeing equal treatment for efficient and inefficient workers alike, even in the context of a capitalist economy. Financial reward was set according to the average performance of members of their professional category and then could not be adjusted downward. The poorer performance of the weakest was offset by the performance of the strongest.... It was a mechanism that was fairly well aligned with a production model in which workers had the prospect of continuing to do the same work for 30 or 40 years in the same company, irrespective of performance, until their retirement. Since the 80 s, however, production 
and products have evolved rapidly, the global economy has affirmed itself, small and medium enterprises are set up and shut down quickly, and workers are beginning to experiment with various forms of collaboration without any guarantee of stability (fixed-term contracts, training contracts, temporary work, autonomous collaboration, etc.).

With the beginning of the third millennium and the spread of markets marked by oversupply, companies have to deal with the global dimension of business, for which: the company organisation is structured as a network (geographically dispersed and with multiple propulsive business centres); performance results are assessed through multiple indicators, where intangible corporate assets and intangible product assets lie alongside (and often condition) tangible company elements; the unity of governance ${ }^{6}$ must harmonize with the variety and specificity of management geared towards enhancing market diversity, ethnicity and culture; and finally, corporate responsibility consequently experiences a new and complex evolution, which comprises the results of the organization at a local and global level within an overall context of compatible development.

Corporate responsibility in global markets therefore systematises the attaining of financial results and the achievement of sustainable growth; in other words, generating value for management and shareholders, while improving and enhancing, over time, the natural environment, the social context and the human resources. In line with this global vision of compatible development, corporate social responsibility becomes externalised and closely related to stakeholders, thereby acknowledging the centrality of the global and local media in the competitive governance of the company consensus, namely the company's relations with its stakeholder system.

\section{Global Markets and Corporate Competitive Space}

Corporate development based on 'enlarged' competitive space (market-space management) tends to generate mega-organizations with very strong 'top tier management power' that can even go so far as to create international ethical problems (as in the case of Enron).

Global networks that operate in enlarged competition spaces (enhancing and exploiting the intangible assets, i.e. brand equity, information system and corporate culture), have access to so extensive and sophisticated market information, that they are able to compete with governments in setting local development guidelines.

Thus, nowadays, companies face one other under conditions of high and constant competitive tension in a global context and subject to political, social and technological instability. No company can, therefore, trust, as in the past, solely in its own resources, knowledge and skills, since corporate development is created with the help of different 'carriers' (shareholders, managers; employees, customers and competitors).

'Shareholders demand value creation is closely related to growth. Employees seek career advancement, financial rewards, job security, and job satisfaction. Then there is a heat from competitors, particularly 
in industries such as banking, pharmaceuticals, automotive, defence, airlines, and personal computer which are undergoing consolidation. Here growth is essential if economies of scale in technology development, operations, capacity utilization, marketing, distribution and network externalities are to be captured. Those companies which fail to expand as fast as competitors will lose competitive advantage and enter a downward spiral'?

The new global context of competition has especially brought about profound changes to the role of strategic alliances and made necessary the introduction of collaborative networks between groups of companies of similar size and profile. Indeed, multinationals from developing economies are organising themselves to compete globally (typically in networks and constellations of enterprises), while the leading multinationals from industrialized economies promote multiple means of competing cooperatively through strategic alliances in the form of equity alliances or non-equity alliances.

In brief, the main factors affecting corporate competitiveness in global markets ${ }^{8}$ can be attributable to:

- rapid changes to the competitive base. A competitive edge acquired in a given field of activity does not remain for long if the company does not develop innovation with continued product progress and the relentless search for 'unfilled' demand (demand bubble management);

- globalisation of business organizations. Over the past two decades, increasingly widespread over-supply ${ }^{9}$ worldwide has led many large corporations to develop expansion plans, in line with a vision of a global company ${ }^{10}$, by reorganising their distinctive competitive competence in the search for broader boundaries of scale economies (market-space management) ${ }^{11}$;

$\square$ 'Globalisation is related to scale economies. Firms are trying to tap market opportunities in huge markets such as China, India and Russia. In a more interconnected world, firms not only from developed countries but also from third world countries have joined international competition. It is interesting to see a porter or a street vendor in a developing country using a mobile phone services in markets where (with the wiring connections) such a service was impossible, ${ }^{, 2}$.

- development of hybrid sectors. The emergence of new technologies and the push to disseminate new products and services tend to confuse the demarcation boundaries of traditional sectors of activity. One of the best and most evident examples of this can be seen in the ever closer convergence between the telephony, television and cable communication sectors. Even the most traditional sectors, such as industry and medical products, are markedly characterized by emerging industries (such as computers, robots, lasers, etc.) and certain new activities can be classified as 'hybrid sectors';

- strategic alliances. In global and over-supplied markets, a competitive relations increasingly tend to interweave with specific collaborative relations. Indeed, in situations of highly-intensive competition, the setting up 
of lines of cooperation represents typical strategic behaviour by companies with a long-term view and global market vision. Companies can set competitive strategic alliances with a wide range of solutions of equity alliances and non-equity alliances.

\section{Networking, Local \& Global Performance and Corporate Responsibility}

Strategic alliances for competitive collaboration highlight the common feature of the 'competitive network' with which companies engaged in global markets and conditions of over-supply must currently operate. Another feature is that - in order to be truly 'shared' and long-lasting and so avoid cases like Enron and Parmalat company performance at a local level and at a global level (corporate) requires a new concept of corporate responsibility, whereby sustainable growth is the baseline for corporate development. In particular, strategic equity alliances can be further categorized as follows:

- International Joint Venture (IJV);

- Equity participation, whereby a company owns a capital stock in other companies in order to be in a position to either control or influence actions and activities.

'By using their ownership leverage, the investor can get information from and influence the new initiative of the target companies. GM, for example, has effectively used its equity participation on Isuzu and Suzuki to penetrate the Japanese automobile market by co-production and comarketing. GM also used its Japanese partners in venturing with other Japanese automobile manufacturers. Similarly, Daimler Chrysler took a controlling 34 percent stake in Japan's Mitsubishi Motors and is in the early stages of planning a 'world car' jointly with its Japanese partner and South Korea's Hyundai Motors, in which Daimler Chrysler holds 10 percent equity stake, 13 .

In contrast, strategic alliances which are not based on share-holding (non - equity alliances) set out different forms of contractual arrangements. These might specifically cover agreements for:

- Co-production, which occurs when several businesses work together to manufacture a certain product. If each participating company specializes in producing specific parts of an asset or in developing processes geared towards minimising costs or differentiating a product, the joint development of production process aims to achieve a final product with superior features.

GM and Fuji Heavy Industries agreed upon manufacturing cars together. GM will benefit from Fuji's strengths in all-wheel drive and continuously variable transmissions, while Fuji will benefit from GM's research on alternative power plants and other environmental orientations. The alliance will focus initially on the design and manufacture of small and mid-size sport-utility and crossover vehicles. 
In reference to an entirely new cooperation, GM and Honda decided to collaborate on the production of hybrid and diesel engines.

- $R \& D$ Partnership, whereby companies allocate defined resources and distinct skills in order to share the costs of a specific and particularly expensive research project, or combine human resources and technological capabilities to introduce or develop precise innovations. The sharing of knowledge and experience by different partners, on the one hand helps cut technological development time, with reduced costs for each company, and, on the other hand, highlights the fact that current production technology constitutes a complex and sophisticated system that covers different industrial sectors so businesses rarely have the full range of technical skills necessary to create new products and services.

'IBM, Infineon Technologies Inc. (formerly Siemens) and United Microelectronics Corp. (UMC) have unveiled their $R \& D$ partnership for making integrated circuits based on 0.13-and 0.10- micron copperwired Complementary Metal-Oxide Semiconductors processes. They hope that the combined efforts of IBM, Infineon and UMC will result in the availability of the world's most advanced processes. Research will be conducted by engineers and scientists staffed by all three companies at the IBM Semiconductor Research Center in the United States, ${ }^{14}$.

- Outsourcing. External supply agreements have become very widespread in recent years. These agreements were initially aimed at simple reducing production costs. In more recent times, however, they are also becoming a competition-related factor, involving suppliers' R\&D capacities and expanding the operational framework to a network level.

$\square$ 'Nike discovered years ago that it can pay to let somebody else do your manufacturing. Its skills were in research, marketing and distribution. Others are increasingly making the same calculation. Five years ago Timberland produced $80 \%$ of its shoes in its own plants. Today, it produces just $18 \%$ by itself. Also Motorola unveiled plans to outsource consumer-electronics production with Flextronics International Ltd ${ }^{15}$.

- Supply-Chain Partnership. Many multinational companies have set up longterm relations with a select number of suppliers who undertake to punctually deliver parts and components of a predetermined quality. These close links between producers and suppliers are motivated by benefits gained from justin-time (JIT) inventory management systems, which in practice aim to eliminate stocks by closely coordinating production times and supplier delivery times ${ }^{16}$.

$\square$ The idea behind the JIT system is that large companies such as GM, Toyota and GE have billions of dollars tied up in inventories. Then any savings in inventory cost improves the firm's productivity. The JIT 
system originated in Japan and is effectively utilized by many Japanese companies, including Toyota, Nissan, Honda, Sony and Matsushita.

- Cooperative Marketing. Joint marketing programs are carried out when companies from different countries or multinationals present in several markets sign reciprocal marketing agreements relating to the introduction and/or business development of given products in defined markets for a defined period of time. Joint marketing agreements occur, therefore, when it is advantageous to penetrate set national markets without making any direct investments that could not be justified given the limited sales volume involved.

- Licensing. This type of agreement provides a means of entering a new market without substantial investment and, still with very limited investment, testing a foreign market with a new product launch or acquiring specific know-how. Licensing entails, however, specific risks where the licensee may become a competitor, even copying specific technologies or trademarks, or marketing special processes or licensed trademarks.

- Franchising. With this formal agreement, the franchisor grants a franchisee, via contractual agreement, the opportunity to use a trademark, a sales system and other proprietary rights, in exchange for an amount calculated on sales volume.

In recent years, there has been an explosion of franchising throughout the world due to the expansion of major franchising companies such as Coca-Cola, PepsiCo, MacDonald's, Burger King, Kentucky Fried Chicken, Hilton Hotels and Holiday Inns. It is common to see the franchisor mandating that the franchisee must buy the equipment and some key ingredients from the franchisor. For example, McDonald's and Burger King dictate in their franchising agreements that the franchisee should buy from them the cooking equipment and other company-specified products.

Market-space competition conditions therefore tend to shape a company as a viable complex competition-oriented system with competitive boundaries that go beyond the traditional dimensions of space and time (i.e. a traditional circumscribed environment that allows a company to measure, at any specific moment, its performance and competitive position - and thus potential dominant position - using a basic company-goods-market equation).

Global organisations - precisely because of market forces (which may lead stronger networks towards positions of global oligopoly) and geographic dissemination (caused by the same expansionist nature of 'market-space competition') - reveal, however, conspicuous 'Achilles heels' when seeking to affirm solid local leadership. In this respect, corporate responsibility requires a specific qualification - corporate social responsibility - as a result of the need to face the potential mistrust, thoughts and feelings of opinion makers (consumers, 
shareholders, employees, suppliers, media, etc.), who are increasingly interconnected, well-informed and delocalised with respect to the production and consumption of goods.

\section{Corporate Responsibility and Corporate Social Responsibility in Global Markets}

From a managerial perspective, corporate responsibility, in general terms, is linked to an unequivocal clearly-identified concept. In other words, the fundamental responsibility of government and management is 'to ensure the lasting pursuit of the company mission, seeking increasing levels of quality and efficiency , 17

As evidence of this, corporate responsibility tends to take different forms in relation to the different competitive conditions in which an organization operates. In this regard, it is especially evident that in local markets (which often reflect economies of scarcity, with demand largely exceeding supply capacity and with companies in a monopolistic or quasi-monopolistic position), corporate responsibility in the main seeks profitability as the primary goal. Consequently, in real terms, conditions of company wellbeing simply reflect corporate social responsibility, where company growth (especially in terms of increased turnover and the number of workers employed) is directly associated with the development of relations with the environment as well as social relations (inside and outside the organization).

$\square$ 'The corporation is an instrument of the stockholders who own it. If the corporation makes a contribution, it prevents the individual stockholder from himself deciding how he should dispose of his funds. If charitable contributions are to be made, they should be made by individual stockholders, or by extension individual employees, and not by the corporation, ${ }^{, 18}$.

On the other hand, corporate responsibility and corporate social responsibility take on a different form when companies have to operate in markets with dynamic equilibrium between supply and demand, namely during the development phase for companies in international markets, where the headquarters of the parent companies lay down the rules of conduct for the subsidiaries, which then operate under a common set of rules stipulated from the centre (although potentially aligned to meet special local requirements).

$\square$ 'Corporations can use their charitable efforts to improve their competitive context the quality of the business environment in the location or locations where they operate... Most corporate expenditures produce benefits only for the business, and charitable contributions unrelated to the business generate only social benefits. It is only where corporate expenditures produce simultaneous social and economic gains that corporate philanthropy and shareholder interests converge... Philanthropy can often be the most-effective way for a company to 
improve its competitive context, enabling companies to leverage the efforts and infrastructure of nonprofits and other institutions. If systematically pursued in a way that maximizes the value created, context-focused philanthropy can offer companies a new set of competitive tools that well justifies the investment of resources ${ }^{19}$.

$\square$ 'Downsizing has transformed the management of corporate philanthropy in the United States. Forced to explain why business should give away money while laying off workers... have come up with an approach that ties corporate giving directly to strategy... In short, the strategic use of philanthropy has begun to give companies a powerful competitive edge... companies have become corporate citizens... cultivate a broad view of their own self-interest while instinctively searching for ways to align self-interest with the larger good... Already powerful in the United States, corporate citizenship promises to bring even more success to U.S. companies internationally, particularly in emerging markets like Taiwan, Brazil and Hungary. In such countries, which are still uncluttered by social initiatives, even small well-conceived grant programs can have a large impact,20.

In international managerial economics, and in line with the logic of exporting goods and the top-down dissemination of parent company corporate culture, corporate responsibility maintains a solid monolithic position. Within this, however, it is necessary to balance out the growth of the central organization (according to quantitative parameters of profitability, but by also striving for intangible factors of development such as company identity) and the basic economic performance of the subsidiary (profitability; turnover; effective and efficient management). These are also generally matched by excellent pro tempore local conditions in compliance with the social and/or environmental expectations of the host country. In this sense, corporate social responsibility tends to be of an independent and clearly-distinct nature, with a strong local 'flavour' although always within a marked centre-periphery monodirectionality that finds its 'raison d'être' in the strong institutional stability and competitiveness of those markets where export economies prevail.

In the framework of international managerial economics, corporate responsibility therefore acknowledges the existence of diversity in individual operating environments and, therefore, corporate social responsibility is designed to interface with the social and environmental phenomena of the various markets, which - furthermore - must be respected and managed to ensure the company's successful development locally (and consequently successful corporate development).

In global markets, by contrast, corporate responsibility must ensure lasting pursuit of its mission within a framework of an open and unstable competitive system. This global context, above all, requires the development of network organizations and, increasingly, cooperative forms of agreement such as equity and non-equity alliances, which bring about the development of new organizational models between the centre and periphery ${ }^{21}$. 
'Many global companies believe they have a moral duty to respond to a world's problems but are unsure how to do that a still pursue a reasonable profit for their shareholders... Canon suggest that companies consider 'kyosei', a business credo that he defines as a 'spirit of cooperation' in which individuals and organizations work together for the common good... The implementation of 'kyosei' can be divided into five stages: 1. economic survival; 2. managers and workers resolve to cooperate with each other; 3 . cooperate outside the company. Cooperation is extended to customers, suppliers community groups, and even competitors; 4. global activism. Company takes the cooperative spirit beyond national boundaries; 5. the government as a 'kyosei' partner. When a company has established a worldwide network of 'kyosei' partners, using their power and wealth, fifth-stage corporations urge national governments to work toward rectifying global imbalances (trade, income, labour, environment) ${ }^{22}$.

Consequently, the global economy delineates a corporate responsibility which is dominated by externalities of social and environmental relations and which, therefore, must balance the aim of company profitability with the objective of sustainable growth within a dynamically-equilibrated system ${ }^{23}$.

Corporate responsibility in global markets therefore aims to pursue business results (local and corporate) that feature high levels of profitability and efficiency, but also a priority concern for sustainable development. Corporate responsibility in a global context is consequently in practical terms finalized by corporate social responsibility, which can be defined in accordance with the statement made in the Green Paper drawn up by the European Commission in July 2001 declaring, 'the voluntary inclusion of a company's social and environmental concerns in its commercial operations and dealings with stakeholders ${ }^{24}$. Such a definition actually reflects the vision of EU and European concerns (very sensitive to the new Europe comprising ${ }^{25}$ countries and therefore perhaps slightly biased in a global market increasingly oversupplied) which focus on: 'company membership on a voluntary basis'; 'the extension of CSR to include small businesses' (which in fact sometimes encompasses finding spaces for public funding without impacting on Community regulations); and especially 'the primacy of social relations in terms of work and employment', whilst tending to place in a lesser position of importance 'environmental sustainability' (which is instead at the forefront of CSR for global US companies) and the search for commercial equity/non-equity co-makership and research relationships (i.e. at the forefront of CSR for Japan or China-based companies).

In a global economic perspective, it can, therefore, be useful to overcome the constraints posed by the EU vision and note that US companies nowadays tend to follow a very pragmatic interpretation 25 , by which they define the corporate social responsibility as 'an action by a firm, which a firm chooses to take, that substantially affects an identifiable stakeholder's social welfare ${ }^{26}$.

In any case, evidently, the corporate social responsibility can not be confused with the actions of promotion/corporate identity protection, which in practice are linked to publicity programs or even corporate advertising and pursue objectives linked to improving the corporate image and, as such, are totally contradictory to 
defining relations between a company and its socio-environmental context. In reality, actions of promotion/ company identity protection follow 'consensus management' objectives with locally-oriented short-term perspectives These are generally managed by public relations agencies and referred to as cause-related marketing; an appealing (if totally inappropriate) term coined by PR professionals.

'Increasingly, philanthropy is used as a form of public relations or advertising, promoting a company's image or brand through causerelated marketing or other high-profile sponsorships... Not surprisingly, there are genuine doubts about whether such approaches actually work or just breed public cynicism about company motives... Cause-related marketing, through which a company concentrates its giving in a single cause or admired organization, was one of the earliest practices cited as 'strategic philanthropy', and it is a step above diffuse corporate contributions. At its most sophisticated, causerelated marketing can improve the reputation of a company by linking its identity with the admired qualities of a chosen no-profit or popular cause... However, cause-related marketing fall far short of truly strategic philanthropy. Its emphasis remains on publicity rather than social impact. The desired benefit is enhanced goodwill, not improvement in a company's ability to compete ${ }^{27}$.

'In short, a company proves itself to be truly responsible when it is a viable concern and when this is demonstrated by: first of all, profitability and growth observed over a number of years; and, at the same time, by its socially-oriented approach, where social orientation is shown above all by a commitment to meet the legitimate expectations of all stakeholders, starting with the employees and shareholders ${ }^{28}$.

'Corporate citizenship is about companies taking into account their complete impact on society and the environment, not just their impact on the economy. It is about business assuming responsibilities that go well beyond the scope of simple commercial relationships. Good corporate citizenship can provide business benefits in eight areas: reputation management; risk profile and risk management; employee recruitment, motivation and retention; investor relations and access to capital; learning and innovation; competitiveness and market positioning; operational efficiency; license to operate... Reputation is critical to corporate success... Reputations are built and maintained by a firm's relative success in fulfilling the expectations of multiple stakeholders. Companies have a range of stakeholders and understanding their expectations is critical to managing risks to the business and maintaining a positive reputation, 29 .

In global markets, relations between firms and societies play a critical priority and determinant role in, on the one hand, the management of diversity in the social and environmental systems in which they are present; and, on the other, in the competitive forces and tensions linked to the stakeholders system. In the latter, it is 
a case of aiming to identify beforehand, and therefore solve, social and environmental problems arising as a result of competitive activity. This means placing at the very heart of corporate strategies stakeholder expectations (which in global companies, by definition, are very numerous and differentiated) and the principle of continuous improvement and innovation to be pursued with productmarket permutations under unstable and variable competitive conditions (task management).

Therefore, in a global managerial perspective, corporate responsibility is required to deal positively with specific social and environmental conditions pertaining to each operating context. This context, consequently, does not qualify as being referred to as 'local phenomena of divergence' but rather as 'elements of competitive market characterization', namely organisational components of which it is essential to know the evolving trends in order to ensure the company's or companies' local and global growth. In global companies, corporate social responsibility is, hence, targeted at managing the stakeholder system (i.e. all those with an organizational, social or environmental interest). Furthermore, having originated in specific local markets and by referring to well-defined circumstances, it can still be expressed and interact at a global scale and generate multiple effects, even in different contexts, due to the increasing permeability of companies to communication.

\section{Bibliography}

Annan K., The Global Compact. Corporate Leadership in the World Economy, Symphonya. Emerging Issues in Management (symphonya.unimib.it), n. 2, 2002. http://dx.doi.org/10.4468/2002.2.02annan

Bartlett C.A., Ghoshal S., Transnational Management, McGraw-Hill, 1992.

Bowen H.R., Social Responsibility of the Businessman, Harper \& Row, New York, 1953.

Brondoni Silvio M., Ouverture de 'Market-Space Management', Symphonya. Emerging Issues in Management, (symphonya.unimib.it), n. 1, 2002. http://dx.doi.org/10.4468/2002.1.01ouverture

Brondoni Silvio M., Global Markets and Market-Space Competition, Symphonya. Emerging Issues in Management (symphonya.unimib.it), n. 1, 2002. http://dx.doi.org/10.4468/2002.1.03brondoni

Culpan Refik, Global Business Alliances: Theory and Practice, Quorum Books, Westport, 2002.

Dainesi L., Zucchella A., Marketing in the Wireless Context, Symphonya. Emerging Issues in Management (symphonya.unimib.it), n. 1, 2002. http://dx.doi.org/10.4468/2002.1.06dainesi.zucchella

de Woot Philippe, The Challenges of Economic Globalisation: Business, Competition and Society, Symphonya. Emerging Issues in Management (symphonya.unimib.it), n. 2, 2002. http://dx.doi.org/10.4468/2002.2.03dewoot

Esposito De Falco S., Competizione globale e forme di potenziamento della governance, Sinergie, January-April 2003, pp. 163-188.

Freeman R.E., A Stakeholder Theory of the Corporation, T.L. Beauchamp, N.E. Bowie (eds.), Ethical Theory and Business, 6th. ed., Prentice-Hall, Englewood Cliffs, 2001, pp. 56-65.

Friedman M., Capitalism and Freedom, University of Chicago Press, Chicago, 1962. 
Frooman J., Socially Irresponsible and Illegal Behavior and Shareholder Wealth: A Meta-Analysis of Event Studies, Business \& Society, n. 3, 1997, pp. 221-249.

http://dx.doi.org/10.1177/000765039703600302

Golinelli Gaetano M., Vagnani Gianluca, Corporate Governance as a Viable System: the Role of Intra- and Inter-Systemic Relationships, Symphonya. Emerging Issues in Management (symphonya.unimib.it), n. 2, 2002. http://dx.doi.org/10.4468/2002.2.07golinelli.vagnani

Griffin J.J., Mahon J.F., The Corporate Social Performance and Corporate Financial Performance Debate: Twenty-Five Years of Incomparable Research, Business \& Society, n. 36, 1997, pp. 5-31. http://dx.doi.org/10.1177/000765039703600102

Hilsenrath J.H., Overseas Suppliers to U.S. Brands Thrive, The Wall Street Journal, March 10, 2000, p. A18.

Hitt M.A., Ireland R.D., Hoskisson R.E., Strategic Management: Competitiveness and Globalisation, 3rd ed., South-Western College Publishing, Cincinnati, 1999.

Kaku R., The Path of Kyosei, Harvard Business Review, July-August 1997.

Kaounides L.C., Science, Technology and Global Competitive Advantage, International Studies of Management \& Organization, Spring 1999, pp.53-79.

Karnani A.G., Five Ways to Grow the Market and Create value, The Financial Times, October 18, 1999, pp. 8-10.

Lambin Jean-Jacques, Brondoni Silvio M., Ouverture de 'Market-Driven Management', Symphonya. Emerging Issues in Management (symphonya.unimib.it), n. 1, 2000-2001. http://dx.doi.org/10.4468/2001.1.01ouverture

McIntosh M., Leipzinger D., Jones K., Coleman G., Corporate Citizenship, F T Pitman Publishing, London, 1998.

McWilliams A., Siegel D., Corporate Social Responsibility: A Theory of the Firm Perspective, Academy of Management Review, n. 26, 2001, pp. 117-127. http://dx.doi.org/10.2307/259398

Molteni M., L'impresa tra competitività e responsabilità, Impresa e Stato, October-December 2003, p. 23.

Moore G., Corporate Social and Financial Performance: An Investigation in the U.K. Supermarket Industry, Journal of Business Ethics, n. 34, 2001, pp. 299- 315. http://dx.doi.org/10.1023/A:1012537016969

Murphy E., Best Corporate Citizens Have Better Financial Performance, Strategic Finance, n. 83, 2002, pp. 20-21.

Orlitzky M., Does Firm Size Confound the Relationship between Corporate Social Performance and Firm Financial Performance?, Journal of Business Ethics, n. 33, 2001, pp. 167-180. http://dx.doi.org/10.1023/A:1017516826427

Pepe C.., Connotati organizzativi dell'impresa per il mercato globale, Sinergie, January-April, 2003, pp. 103-128.

Perlmutter H.W., The Tortuous Evolution of the Multinational Company, Columbia Journal of World Business, n. 1, 1969, pp. 9-18.

Porter M.E., Changing Patterns of International Competition, California Management Review, n. 2, 1986.

Porter M.E., Kramer M.R., The Competitive Advantage of Corporate Philanthropy, Harvard Business Review, November-December, 2002, pp. 57-68.

Preston L.E., O'Bannon D.P., The Corporate Social-Financial Performance Relationship: A Typology and Analysis, Business and Society, n. 38, 1997, pp. 419-429. http://dx.doi.org/10.1177/000765039703600406 
Robbins S.P., De Cenzo D.A., Fundamentals of Management, Prentice Hall, Upper Saddle River, 1998.

Roberts S., Keeble J., Brown D., The Business Case for Corporate Citizenship, Arthur D. Little, Cambridge, 2002.

Roberts S.., Putting Corporate Responsibility into Practice: Understanding the Patchy Success of Ethical Sourcing Initiatives, Ashridge (ed.), The Changing Role of Business in Society, CAET, London, 2002, p.1.

Roman R.M., Hayibor S., Agle B.R., The Relationship between Social and Financial Performance: Repainting a Portrait, Business \& Society, n. 38, 1997, pp. 109-125.

Ruf B.M.., Muralidhar K.., Brown R.M., Janney J.J., Paul K., An Empirical Investigation of the Relationship between Change in Corporate Social Performance and Financial Performance: A Stakeholder Theory Perspective, Journal of Business Ethics, n. 32, 2001, pp. 143-156.

http://dx.doi.org/10.1023/A:1010786912118

Saraceno P. (ed.), Economia e direzione dell'impresa industriale, ISEDI, 1978.

Simpson W.G., Kohers T., The Link between Social and Financial Performance. Evidence from the Banking Industry, Journal of Business Ethics, n. 35, 2002, pp. 97-109.

http://dx.doi.org/10.1023/A:1013082525900

Smith C., The New Corporate Philanthropy, Harvard Business Review, May-June, 1994.

Velo D., La responsabilità sociale dell'impresa nel mercato globale, Sinergie, January-April 2003.

Waddock S.A., Graves S.B., The Corporate Social Performance-Financial Performance, Strategic Management Journal, n.18, 1997, pp. 303-319.

Worrel D.L., Davidson W.N., Sharma V.M., Layoff Announcements and Stockholder Wealth, Academy of Management Journal, n. 34, 1991, pp. 662-678.

Wright P., Ferris S.P., Agency Conflict and Corporate Strategy: The Effect of Divestment on Corporate Value, Strategic Management Journal, n. 18, 1997, pp. 77-83.

Zadek S., The Civil Corporation: The New Economy of Corporate Citizenship, Earthscan Publications, London, 2001.

\section{Notes}

${ }^{1}$ Cf. P. de Woot, The Challenges of Economic Globalisation: Business, Competition and Society, Symphonya. Emerging Issues in Management (symphonya.unimib.it), n. 2, 2002.

2 Cf. S.M. Brondoni, Global Markets and Market-Space Competition, Symphonya. Emerging Issues in Management (symphonya.unimib.it), n. 1, 2002.

${ }^{3}$ See H.R. Bowen, Social Responsibility of the Businessman, Harper \& Row, New York, 1953, p. 11.

${ }^{4}$ See D. Velo, La responsabilità sociale dell'impresa nel mercato globale, Sinergie, GennaioAprile 2003, p. 38.

${ }^{5}$ Cf. P. Saraceno (ed.), Economia e direzione dell'impresa industriale, ISEDI, 1978.

${ }^{6}$ Cf. G.M. Golinelli, G. Vagnani, Corporate Governance as a Viable System: the Role of Intraand Inter-Systemic Relationships, Symphonya. Emerging Issues in Management (symphonya.unimib.it), n. 2, 2002; S. Esposito De Falco, Competizione globale e forme di potenziamento della governance, Sinergie, Gennaio-Aprile 2003, pp. 163-188.

7 See A.G. Karnani, Five Ways to Grow the Market and Create value, The Financial Times, October 18, 1999, pp. 8-10. 
${ }^{8}$ The factors of new corporate global competitiveness, in short, qualify the forces that determine current boundaries of rivalry between enterprises. In this respect, we observe that:'...the new competitive landscape is shaped by rapid technological changes and technology diffusion, dramatic changes in information technology and an increasing importance of knowledge...In response to these global economic conditions, firms are in the midst of a revolutionary transformation from industrial-age competition to information-age competition'. See M.A. Hitt, R.D. Ireland, R.E. Hoskisson, Strategic Management: Competitiveness and Globalisation, 3rd ed., South-Western College Publishing, Cincinnati, 1999, pp. 8-10. 'Rapidly changing market conditions ...form the new competitive dynamics, which are knowledge-based and global in nature and require continuous improvements in every facet of the value chain and seeking opportunities worldwide...This new competitive mode requires product and process innovation, quick responses and higher customer service while manoeuvring between competition and cooperation'. See R. Culpan, Global Business Alliances: Theory and Practice, Quorum Books, Westport, 2002, pp. 43-44.

${ }^{9}$ Cf. S.M. Brondoni, Ouverture de 'Market-Space Management', Symphonya. Emerging Issues in Management (symphonya.unimib.it), n. 1, 2002; S.M. Brondoni, J.J. Lambin, Ouverture de 'Brand Equity', Symphonya. Emerging Issues in Management (symphonya.unimib.it), n. 1, 2000-2001.

10 The reference to 'global market' tends to cover the complex issue of modern conduct of corporate competition. In this respect, we should remember some positions that precisely mark the evolution over time of the competitive conduct of large companies in the vast international markets. Perlmutter, writing in the late '60s, maintains that the company philosophy determines the strategic line of action versus international markets and with this vision distinguishes between: ethnocentrism (where strategic choices are centralised in the parent company); polycentrism (where the corporations customise products and processes to meet the needs of each national markets), and geocentrism (where parent companies and subsidiaries operate as a single system). Cf. H.W. Perlmutter, The Tortuous Evolution of the Multinational Company, Columbia Journal of World Business, No 1, 1969, pp. 9-18. Later, Porter introduces an important difference in the conduct of international competition, distinguishing between multi-domestic and global sectors. In the first, competitive relations are highly independent (country-by-country competition), while in global industries the competitive position of a company is significantly influenced by the overall competitive structure (commercial aircraft; defence aircraft; semiconductors; TV apparatus and equipment; cars; machinery for construction and earthmoving). Cf. M.E. Porter, Changing Patterns of International Competition, California Management Review, n. 2, 1986. Finally, with respect to local/global organizational skills and local/global strategic guidance, Bartlett and Ghoshal present four different types of strategic leadership versus foreign markets: international (whereby results achieved outside the country contribute to domestic performance); multinational (products and processes for specific local markets, with country-by-country competitive behaviour); global (with primacy focused on production and economies of scale, compared to the ability to interact with local markets), and finally, transnational (with the advantage of economies with a range of size and specificity). Cf. C.A. Bartlett, S. Ghoshal, Transnational Management, McGraw-Hill, 1992.

${ }^{11}$ Cf. S.M. Brondoni, Global Markets and Market-Space Competition, Symphonya. Emerging Issues in Management (symphonya.unimib.it), n. 1, 2002.

${ }^{12}$ Cf. L. Dainesi, A. Zucchella, Marketing in the Wireless Context, Symphonya. Emerging Issues in Management (symphonya.unimib.it), n. 1, 2002.

\footnotetext{
${ }^{13}$ See R. Culpan, Global Business Alliances: Theory and Practice, cit, p.83
}

14 'Three science-based technological revolutions are currently under way: one is in materials science and engineering, another is in biosciences and biotechnology and the third is in information technologies and the convergence of computers, communications and multimedia content. These advances are multidisciplinary, largely interdependent and are proceeding at a rapid pace from local networks and research centres of excellence located within different national systems of innovation around the world.' see L.C. Kaounides, Science, Technology and Global Competitive Advantage, International Studies of Management \& Organization, Spring 1999, pp. 53-79.

${ }^{15}$ See J.H. Hilsenrath, Overseas Suppliers to U.S. Brands Thrive, The Wall Street Journal, March 10, 2000, p. A18. 
16 'When the JIT system is designed properly, it results in a number of positive benefits for a manufacturer: reduced inventories, reduced setup time, better work flow, shorter manufacturing time, less space consumption and even higher quality. Of course, suppliers who can be depended on to deliver quality materials on time must be found. Because there are no inventories, there is no slack in the system so compensate for defective materials or delays in shipping.' see S.P. Robbins, D. A. De Cenzo, Fundamentals of Management, Prentice Hall, Upper Saddle River, 1998, p. 168.

${ }^{17}$ See M. Molteni, L'impresa tra competitività e responsabilità, Impresa e Stato, ottobre-dicembre 2003, p. 23.

${ }^{18}$ See M. Friedman, Capitalism and Freedom, University of Chicago Press, Chicago, 1962, p. 60.

19 See M.E. Porter, M.R. Kramer, The Competitive Advantage of Corporate Philantrophy, Harvard Business Review, November-December, 2002, pp. 57-68, passim.

${ }^{20}$ See C. Smith, The New Corporate Philanthropy, Harvard Business Review, May-June, 1994, passim.

${ }^{21}$ Cf. C. Pepe., Connotati organizzativi dell'impresa per il mercato globale, Sinergie, GennaioAprile, 2003, pp. 103-128.

${ }^{22}$ See R. Kaku, The Path of Kyosei, Harvard Business Review, July-August 1997, passim.

${ }^{23}$ Cf. K. Annan, The Global Compact. Corporate Leadership in the World Economy, Symphonya. Emerging Issues in Management (symphonya.unimib.it), n. 2, 2002.

${ }^{24}$ European Union Commission's Green Paper on Corporate Social Responsibility, Brussels, in July, 2001. Still in a context of global market economics and with prominent reference to the system of external stakeholders, management literature sometimes suggests the term Corporate Citizenship substantially similar to Corporate Social Responsibility. See M. McIntosh, D. Leipzinger, K. Jones, G. Coleman, Corporate Citizenship, F T Pitman Publishing, London, 1998; S. Zadek, The Civil Corporation: The New Economy of Corporate Citizenship, Earthscan Publications, London, 2001; S. Roberts, J. Keeble, D. Brown, The Business Case for Corporate Citizenship, Arthur D. Little, Cambridge, 2002.

${ }^{25}$ The pragmatic vision of CSR in current US-based corporate culture can be seen by the growing attention to the issue of measurability of corporate social responsibility (understood as 'corporate intangible' and critical to success in a global economy). On the relationship between CSR and Corporate Financial Performance, and with regard to studies showing positive associations, refer to: D.L. Worrel, W.N. Davidson, V.M. Sharma, Layoff Announcements and Stockholder Wealth, Academy of Management Journal, 1991, n. 34, pp. 662-678; L.E. Preston, D.P. O'Bannon, The Corporate Social-Financial Performance Relationship: A Typology and Analysis, Business and Society, 1997, n. 38, pp.419-429; S.A. Waddock., S.B. Graves, The Corporate Social PerformanceFinancial Performance, Strategic Management Journal, 1997, n.18, pp. 303-319; R.M. Roman, S. Hayibor, B.R. Agle, The Relationship between Social and Financial Performance: Repainting a Portrait, Business \& Society, 1997, n. 38, pp. 109-125; M. Orlitzky, Does Firm Size Confound the Relationship between Corporate Social Performance and Firm Financial Performance?, Journal of Business Ethics, n. 33, 2001, pp. 167-180; B.M. Ruf., K. Muralidhar., R.M. Brown, J.J. Janney, K. Paul, An Empirical Investigation of the Relationship between Change in Corporate Social Performance and Financial Performance: A Stakeholder Theory Perspective, Journal of Business Ethics, 2001, n. 32, pp. 143-156; E. Murphy, Best Corporate Citizens Have Better Financial Performance, Strategic Finance, 2002, n. 83, pp. 20-21; W.G. Simpson, T. Kohers, The Link between Social and Financial Performance. Evidence from the Banking Industry, Journal of Business Ethics, 2002, n. 35, pp. 97-109. For an analysis of neutral or negative connections, see instead: J.J. Griffin, J.F. Mahon, The Corporate Social Performance and Corporate Financial Performance Debate: Twenty-Five Years of Incomparable Research, Business \& Society, 1997, n. 36, pp. 5-31; P. Wright, S.P. Ferris, Agency Conflict and Corporate Strategy: The Effect of Divestment on Corporate Value, Strategic Management Journal, 1997, n. 18, pp. 77-83; A. McWilliams, D. Siegel, Corporate Social Responsibility: A Theory of the Firm Perspective, Academy of Management Review, 2001, n. 26, pp. 117-127; G. Moore, Corporate social and 
Financial Performance: An Investigation in the U.K. Supermarket Industry, Journal of Business Ethics, 2001, n. 34, pp. 299- 315.

${ }^{26}$ Cf. J. Frooman, Socially Irresponsible and Illegal Behavior and Shareholder Wealth, Business \& Society, n. 3, 1997, pp. 221-249; R.E. Freeman, A Stakeholder Theory of the Corporation, T.L. Beauchamp, N.E. Bowie (eds.), Ethical Theory and Business, 6th. ed., Prentice-Hall, Englewood Cliffs, 2001, pp. 56-65.

${ }^{27}$ See M.E. Porter, M.R. Kramer, The Competitive Advantage of Corporate Philanthropy, cit., passim.

28 See M. Molteni, L'impresa tra competitività e responsabilità, Impresa e Stato, OttobreDicembre 2003, cit., p.24

${ }^{29}$ See S. Roberts., Putting Corporate Responsibility into Practice: Understanding the Patchy Success of Ethical Sourcing Initiatives, Ashridge (ed.), The Changing Role of Business in Society, CAET, London, 2002, p. 1. 